\title{
The health impact of German unification: still much to learn
}

The division of Germany after the second world war has often been recognised as providing a unique opportunity to evaluate "a natural experiment in history", ${ }^{1}$ one in which a homogenous population had been artificially separated for 45 years. The possible consequences for health of exposure to two very different social models have, however, received relatively little attention.

When the Berlin Wall came down in November 1989, followed by the announcement by the West German Chancellor of a 10 point plan for "overcoming the division of Germany and Europe", leading, eventually, to the unification of the German Democratic Republic (GDR) and the Federal Republic of Germany (FRG), the "natural experiment" entered its second phase.

Unification led to a fundamental transformation in the East, and, initially, a massive economic decline. By the end of 1990 the industrial output had fallen to $49 \%$ of what it had been at the beginning of the year $1990 .^{2}$ The new Länder de-industrialised. By 1991, Gross Domestic Product had dropped to about two thirds of the pre-unification level, accompanied by a massive decline in employment with a loss of about 3.5 million jobs (35\% of the labour force) by the end of 1992; unemployment rose from almost zero at the beginning of 1990 to $15.4 \%$ of the labour force in $1992 .^{3}$

Transformation also had enormous demographic consequences in the East. Birth rate fell by about $60 \%$ after the five years following the fall of the Wall. ${ }^{4}$ Marriages and divorces both declined sharply and, since 1989, about 1.7 million, mainly young East Germans migrated to the West.

Changes of this scale might be expected to have consequences for health. Researchers have concentrated on the immediate effects on objective health indicators such as life expectancy and mortality, reporting a remarkable, though temporary, increase in mortality in the GDR during the transition. ${ }^{5-7}$ This worsening of mortality patterns since 1989 represented a sharp departure from the past $^{8}$ and was referred to as a "mortality crisis". ${ }^{9}$ The deterioration affected mainly young and middle aged men and was especially striking for deaths attributable to external causes. ${ }^{10}$ During the same period, however, mortality figures in the West remained largely unaffected or declined.

In this issue of the journal Thomas Hillen et al examine self rated health in East and West Berlin shortly after unification. ${ }^{11}$ This is of particular interest as the Berlin population may be expected to have experienced the consequences of unification almost instantly. One key finding is that women in East Berlin rated their health worse than East Berlin men. Although this might reflect the particular circumstances of Berlin, comparable results have been reported for Germany as a whole, with East German women assessing their health worse than either their male counterparts or those in the West. ${ }^{12}{ }^{13}$ These findings may have been expected given the worsening conditions regarding labour market participation of East German women since unification. ${ }^{3}$ They are, however, somewhat contradicted by more objective measures such as all cause mortality and life expectancy, showing East German women to be better off than their male counterparts, ${ }^{14}$ even though self rated health is a strong predictor of later mortality. ${ }^{15}$ And while women's health has been affected by the political transition, as shown by a transient increase in all cause mortality between 1989 and 1991, the deterioration was less than among East German men, accounting for a decline in life expectancy of only 0.1 year compared with men, who lost almost one year. ${ }^{6}$ Moreover, life expectancy has improved much more rapidly in East German women from 1991 onwards.

A further key finding of the study presented by Hillen $e t$ al shows that the elderly in East Berlin rated their health significantly worse than those in the West. ${ }^{11}$ This finding may be consistent with the 1991 mortality data for Berlin as shown by the authors. It lacks, however, consistency with the observation that, since unification, all cause mortality among the elderly declined much steeper in East Berlin than in the West, with mortality rates among East Berlin men and women aged over 65 being lower in $1996 .{ }^{16}$

Overall, these findings show that even 10 years after the Berlin Wall came down, there is still a remarkable lack of research on the causes of the relatively good performance in the former GDR regarding mortality and life expectancy and also on the causes of the continuing gap between both parts of Germany.

ELLEN NOLTE

European Centre on Health of Societies in Transition, London School of Hygiene and Tropical Medicine, Keppel Street, London WC1E $7 H T$ (ellen.nolte@lshtm.ac.uk)

1 Light DW. Values and structures in the German health care systems. Milbank Memorial Fund Quarterly 1985;63:615-47.

Sinn G, Sinn H-W. Fumpstart. The economic unification of Germany. Cambridge: MIT Press, 1992

3 Bach H-U, Blaschke D, Blien U, et al. Labour market trends and active labour market policy in the eastern German transformation process 1990-1997. IAB Labour Market Research Topics No. 29. Nürnberg: Institut für Arbeitsmarkt und Berufsforschung, 1998.

4 Grünheid E, Mammey U. Bericht 1997 über die demographische Lage in Deutschland. Z Bevölkerungswissenschaft 1997;22:377-480.

5 Wiesner G, Hoffmeister H, Casper G. Imparitäten zwischen Ost und Westeinige Besonderheiten der Mortalitätsentwicklung nach der Wiedervereinigung Deutschlands. Bundesgesundheitsblatt 1993;36:464-9.

6 Häussler B, Hempel E, Reschke P. Die Entwicklung von Lebenserwartung und Sterblichkeit in Ostdeutschland nach der Wende (1989-1992). Gesundheitswesen 1995;57:365-72.

7 Barth W, Claßen E, Heinemann L, et al. Entwicklung der Herz-KreislaufMorbidität und -Mortalität in Ostdeutschland nach der politischökonomischen Wende. Z Gesundheitswissenschaften 1998;6:120-36.

8 Eberstadt N. Demographic shocks after communism: Eastern Germany, 1989-1993. Population and Development Review 1994;20:137-52.

9 Riphan RT. Die Mortalitätskrise in Ostdeutschland und ihre Reflektion in der Todesursachenstatistik. $Z$ Bevölkerungswissenschaft 1999;24:329-63.

10 Winston FK, Rineer C, Menon R, et al. The carnage wrought by major economic change: ecological study of traffic related mortality and the reunification of Germany. BMJ 1999;318:1647-9.

11 Hillen T, Schaub R, Hiestermann A, et al. Self rating of health is associated with stressful life events, social support and residency in East and West Berlin shortly after the fall of the wall. F Epidemiol Community Health 2000; 54:575-80.

12 Hoffmeister H, Bellach BM. Die Gesundheit der Deutschen. Ein Ost-WestVergleich von Gesundheitsdaten. RKI-Heft 7/1995. Berlin: Robert KochInstitut, 1995

13 Lüschen G, Geling O, Janßen C, et al. After unification: gender and subjective health status in east and west Germany. Soc Sci Med 1997;44:1313-23.

14 Statistisches Bundesamt, ed. Gesundheitsbericht für Deutschland 1998. Stuttgart: Metzler-Poeschel, 1998.

15 Idler EL, Benyamini Y. Self-rated health and mortality: a review of twentyseven community studies. F Health Soc Behav 1997;38:21-37.

16 Depner A. Todesursachen in Berlin 1996. Berliner Statistik 1998;3:119-24. 